\section{Postharvest Development and Transmission of Watermelon Fruit Blotch}

\author{
James W. Rushing, ${ }^{1}$ \\ Anthony P. Keinath, ${ }^{2}$ and \\ Wilton P. Cook ${ }^{3}$
}

\begin{abstract}
AdDITIONAL INDEX WORDS. A cidovorax avenae subsp. citrulli, Citrullus lanatus storage
\end{abstract}

\begin{abstract}
Summary. Watermelon fruit blotch (WFB) symptoms did not appear on healthy watermelon [Citrulluslanatus (Thunb.) M atsum. and $\mathrm{N}$ akai] fruit placed in contact with the diseased surface of other fruit and stored at either 52 or $68{ }^{\circ} \mathrm{F}\left(11\right.$ or $\left.20^{\circ} \mathrm{C}\right)$ for 1 week. After 3 weeks in storage, some WFB transmission was observed and the frequency of transmission was greater at 68 than $52{ }^{\circ} \mathrm{F}$. Surface abrasion of either the healthy fruit, diseased fruit, or both fruit did not promote transmission of WFB compared with unabraded controls. Some healthy fruit harvested from a field with diseased fruit developed very minor symptoms of WFB in postharvest storage, but the symptoms were not severe enough to cause market problems. H arvesting appeared to halt the spread of WFB symptoms on individual fruit with less than $\approx \mathbf{1 0} \%$ of the fruit surface affected at harvest. If care is taken during harvest and grading to exclude diseased fruit, and if proper precooling and subsequent temperature management is implemented for marketable fruit, WFB does not appear to be of concern for the marketing of watermelons.
\end{abstract}

\footnotetext{
Clemson U niversity, Coastal Research and Education Center, 2865 Savannah H ighway, Charleston, South Carolina 29414

South Carolina Agricultural Experiment Station T echnical Contribution No. 4406. This work was supported with a grant from the American Seed Research Foundation. The cost of publishing this paper was defrayed in part by the payment of page charges. U nder postal regulations, this paper therefore must be hereby marked advertisement solely to indicate this fact.

${ }^{1}$ Associate professor of horticulture.

${ }^{2}$ Associate professor of plant pathology.

${ }^{3}$ Professor emeritus of horticulture.
}

W atermelon fruit blotch (WFB) first appeared in commercial fields in the U nited Statesin 1989 (H opkins, 1989), although a similar disease had been described elsewhere earlier (W ebb and Goth, 1965). The causal organism of WFB is a bacterium, A cidovorax avenae subsp. citrulli (Schaad et al.), Willemset al. (1992), and the epidemiology of the diseasehasbeen reviewed in detail ( $L$ atin and H opkins, 1995). Earlier research has been focused on the behavior of WFB in the field because of its devastating impact on watermelon production (H opkins et al., 1993; H opkins and Elstom, 1995). As the disease became more prevalent in the U nited States, industry leaders began to express concerns about the fact that entire loads of watermelons were sometimes rejected by receivers because one or a few fruit with WFB symptoms were found in the load. These concerns about the impact of WFB on marketing watermelons led to the initiation of this project on the postharvest behavior of the disease.

O ur objectives were to determine if 1 ) WFB increases in severity on individual watermelonsin storage; 2 ) apparently healthy fruit harvested from an affected field will develop symptoms of WFB in postharvest storage; 3) WFB can be transmitted from a diseased fruit to an apparently healthy fruit in storage; 4) abrasion of the fruit surface, which can occur in postharvest handling systems, would facilitate transmission of the WFB; and 5) postharvest disease development and transmission is influenced by temperature in the storage environment. An understanding of the postharvest behavior of WFB will bethe basis for recommendations for the control of WFB in the marketing chain.

\section{Materials and methods}

Seedling Production. In 1996 and 1997, 'Royal Charleston' watermelon seeds that tested positive for infection with $A$. avenae subsp. citrulli were obtained from Petoseed Company (Saticoy, C alif.). Additional 'Starbrite' seedswithout A. avenae subsp. citrulli infection were obtained from Asgrow Seed Co. (Kalamazoo, M ich.). All seeds were planted in Speedling trays (Sun City, Fla.) with 1-inch cellsusing ScottsM etro M ix 300 as medium (Scotts-Sierra, $M$ arysville, O hio). T rays were placed in atemperature-controlled room at $86^{\circ} \mathrm{F}$ $\left(30{ }^{\circ} \mathrm{C}\right.$ ) until seedling emergence had begun, then transferred to a green- house. Plants were irrigated as needed and fertilized about every $10 \mathrm{~d}$ with Peters Professional 9-45-15 (GraceSierra, M ilpitas, Calif.) according to label directions.

FieLd PROdUCTION. About 1 month after planting, seedlings of $\approx 3$ inches $(7.5 \mathrm{~cm})$ in height were transplanted to a field at the Coastal Research and E ducation Center (CREC), C harleston, S.C. The two varieties were evenly spaced throughout the field and no attempt wasmade to avoid transmission of WFB from one variety to the other during transplanting. Recommended practices for commercial production were followed (Cook et al., 1995), except that frequent light irrigation was implemented to facilitate disease development. The size of the planted area was $\approx 1.2$ acres $(0.5 \mathrm{ha}$ ). The same field was used in 1996 and 1997 to produce plants from both varieties. An additional field (1.2 acres), remote from the WFB infested field, wasused in 1997 to produce healthy 'Starbrite' watermelons.

In 1996, Clemson U niversity Extension staff reported that a commercial planting of 'R oyal Sweet' watermelon in Bamberg County, S.C., was affected with WFB. Thisfield wasused to harvest fruit with WFB. In 1997 there were no reports of WFB in commercial fields in South Carolina.

HaRVESTING. On the morning of 19 J une 1996, $\approx 200$ 'R oyal Sweet' watermelonsinfected with WFB wereharvested from the commercial field in Bamberg County. The percentage of fruit surface showing WFB symptoms was visually estimated and fruit within therange of $10 \%$ to $25 \%$ diseased surface area were selected for the postharvest evaluation. On the afternoon of the same day, $\approx 200$ 'Starbrite' fruit with no visible symptoms of WFB were selected from the planting at the CREC. All of the harvested fruit were placed in a shaded area and the storage trial was initiated the following morning.

In 1997, healthy 'Starbrite' watermelons produced in the isolated field at the CREC were utilized for the disease transmission component of the study. On 8J uly, healthy 'StarB rite' watermelons were harvested, carefully examined for the presence of WFB, and 22 of the best qualitymelonswithoutWFB symptoms were placed at each storage temperature ( 52 and $68{ }^{\circ} \mathrm{F}$ ) to be used later for the diseasetransmission experiment. An additional 22 fruit were placed at 
each temperature as a control.

D evelopment of WFB on 'Royal Charleston' in theinfested field at CREC was substantially delayed in 1997 compared with 1996, possibly due to the unusually cool temperatures that prevailed during the 1997 growing season (H opkins, 1997). D uring the period of 15 to 29 July, the infested field was monitored daily and a total of 44 'R oyal Charleston' fruit with WFB symptoms affecting less than $\approx 10 \%$ of the fruit surface were harvested to beutilized for the disease transmission experiment.

PosthaRVEST TRANSMISSION OF DISEASE. In 1996, 70 healthy 'Starbrite' watermelons were placed at each storage temperature [52 and $68{ }^{\circ} \mathrm{F}$ (11 and 20 $\left.{ }^{\circ} \mathrm{C}\right)$ ]. I nfected 'Royal Sweet' fruit, based on the presence of visual symptoms, were utilized to determine if WFB could be transmitted from the infected fruit to the healthy fruit. $\mathrm{H}$ ealthy watermelons, not in contact with diseased watermelons, were utilized as the control and designated treatment $A$. In treatment $B$, healthy fruit were placed in contact with the diseased area of an infected fruit with neither fruit surface abraded.

In a series of abrasion treatments, the fruit surface was abraded with sandpaper to cause superficial injury similar to that which is often observed in normal handling systems. M edium grade sandpaper was cut into pieces $\approx 1.25$ inches ${ }^{2}\left(3 \mathrm{~cm}^{2}\right)$ and a clean piece of sandpaper was used to lightly score the surface of selected melons before they were placed in contact with each other as follows: treatment $C$, healthy unabraded paired with diseased abraded; $D$, healthy abraded paired with diseased unabraded; and $E$, healthy and diseased fruit both abraded. Abraded areas and diseased areas of different melons were placed in direct contact.

T wo unabraded 'Starbrite' melons were stored at each temperature as controls. All other treatments had three pairs of fruit per replication. This design wasrepeated fivetimesat each temperature. D ata were analyzed as a split-unit design with temperature as the main unit and treatments as split units.

In 1997, abrasion treatments were not included in the WFB transmission study because there had been no apparent effect of the abrasion treatments in 1996 and we had a limited number of fruit with WFB in 1997. I nfected 'R oyal Charleston' fruit wereused asthesource of WFB. H ealthy 'Starbrite' watermelons, produced in the noninfested field, were used to determine if postharvest WFB transmission could occur. The diseasetransmission studyincluded treatments A and B as described for 1996. 'Royal Charleston' fruit harvested on each of seven dates were treated as replications, which resulted in seven replications with one to six pairs of fruit per replication. There were a total of 22 pairs of fruit at each temperature.

Postharvest InCREASE IN SEVERTTY OF WFB ON INDIMDUAL WATERMELONS. In 1996, 30 'Starbrite' and 10 'Royal Charleston' watermelons were selected with diseased areas ranging in diameter from $\approx 1.25$ to 4 inches $(3$ to $10 \mathrm{~cm}$ ). The area showing symptoms on each fruit was outlined in indelible ink, then 15 'Starbrite and 5 'Royal Charleston' fruit were placed at each of the two storage temperatures to observe if the area with symptoms increased during the 3-week storage period.

Postharvest deVElopment OF WFB SYMPTOMS ON FRUIT THAT WERE SYMPTOMLESS AT HARVEST. In 1996, the control fruit described earlier as Treatment $A$ served as a means of observing the development of WFB on fruit that did not have symptoms of WFB at the time of harvest but were grown in an infested field. In 1997, two approaches were taken. The control fruit identified earlier as treatment A consisted of symptomless 'Starbrite' fruit harvested from a noninfested field.

Additionally, on 11 July, 'Starbrite' and 'Royal Charleston' fruit without WFB symptoms were harvested from the infested field. These fruit served as another control to observeifWFB symptoms develop postharvest on symptomless fruit harvested from an infested field. Twenty-five 'Starbrite' and seven 'R oyal C harleston' were placed at $52^{\circ} \mathrm{F}$. Eighteen 'Starbrite' and seven 'Royal Charleston' were placed at 68 ' $\mathrm{F}$.

\section{Results}

OccurRence OF WFB SYMPTOMS ON TRANSPLANTS AND FRUIT IN THE FIELD. In 1996, visual symptoms of WFB as described byL atin and $\mathrm{H}$ opkins(1995) were apparent on leaves of 'R oyal Charleston' within 1 week after seedling emergence, but wereabsent from 'Starbrite'. Within 1 month after transplanting, WFB symptoms were observed on some plants of both cultivars in the field.

In 1997, WFB symptomson transplants developed in a manner similar to the 1996 study. Once the seedlings were transplanted to the field, additional WFB symptoms on the foliage appeared substantially later ( $\approx 15$ J une) and were less severe than observed in 1996, possibly due to the prevailing cool, dry weather in the 1997 season (H opkins, 1997).

In 1996, nearly all of the fruit of 'Royal Charleston' at the CREC developed symptoms of WFB as they neared harvest maturity. Fruit quality deteriorated drastically before 'Starbrite' had reached harvest maturity. For this reason, diseased 'Royal Sweet' fruit were harvested from the commercial farm for use in the study on postharvest transmission of the disease. About $25 \%$ of 'Starbrite' fruit in theC REC field developed symptoms of WFB as they neared harvest maturity in the field, but there weresufficient numbersof symptomless fruit to conduct the postharvest studies. In 1997, the first WFB symptoms were noted on 'R oyal Charleston' fruit on 15 July 1997.

Postharvest increase in WfB SeverITY ON INDIMDUAL FRUIT THAT HAD SYMPTOMS AT HARVEST. In 1996, all fruit were evaluated weekly for 3 weeks to observe increases in the diseased areasthat had been delineated with indelibleink. After 1 week, none of the fruit at 52 of showed an increase in the affected area. At $68{ }^{\circ} \mathrm{F}$, affected areas on 'Starbrite' fruit had not increased and only one of the 'Royal Charleston' fruit had an estimated increase of $20 \%$ in the diseased area.

After 2 weeks, blotch symptoms on fruit at 52 of still had not worsened. At 68 'F , 3 of the 15 'Starbrite' had an estimated increase of blotch symptoms of 5\%to $10 \%$ 'R oyal Charleston' fruit had not changed since the first week'sevaluation, with only onefruitshowing an increasein severity. In sharp contrast, fruit with blotch symptoms in the field rapidly worsened and decayed within a few days.

After 3 weeks, fruit at $52{ }^{\circ} \mathrm{F}$ had minor increases in the area of blotch symptoms with two of the 'Royal Charleston' and two of the 'Starbrite' showing increases of $\approx 10 \%$ At 68 \% , no additional 'Starbrite' fruithad increased blotch symptoms, but the three fruit that wereworsening in the 2-week evaluation continued to develop a larger area of blotch. O ne of the three had $\approx 100 \%$ more area affected than at harvest time and the other two had increased to $\approx 50 \%$ greater area than at harvest time. N one of the 'Royal Charleston' had an increase in diseased area. R emoving the watermelons from the vine when the blotched area was no greater than 4 inches $(10 \mathrm{~cm})$ in diameter dramatically 
reduced the further development of symptoms compared to fruit that were not harvested.

Postharvest development of WFB ON FRUIT THAT WERE SYMPTOMLESS AT HARVEST. In 1996, one of the 10 control fruit (treatment A) at each temperature had developed a diseased area of $\approx 1$ inch $(2.5$ $\mathrm{cm}$ ) in diameter after 3 weeks in storage. Theaffected areawasso small and obscure that it would not have been of consequence to the marketing of the fruit.

In 1997, healthy 'Starbrite' fruit harvested from a noninfested field did not develop symptoms of WFB at either storagetemperatureafter 3 weeks. Symptomless fruit harvested from the infested field did not develop symptoms of WFB at $52^{\circ} \mathrm{F}$ at any time during the storage period. Of the 25 fruit stored at $68{ }^{\circ} \mathrm{F}, 2$ developed very minor symptoms of WFB during the third week of storage. T issue samples from these fruit were cultured in the laboratory. A cidovorax avenae subsp. citrulli was not isolated from thesesamples, indicating that if the bacterium was indeed present, it was superficial in nature as were the symptoms.

PosthaRVest tRansmission OF WFB FROM INFECTED TO SYMPTOMLESS FRUIT. I the 1996 study, none of the 'Starbrite' fruit in any treatment at either temperaturehad developed symptomsof blotch

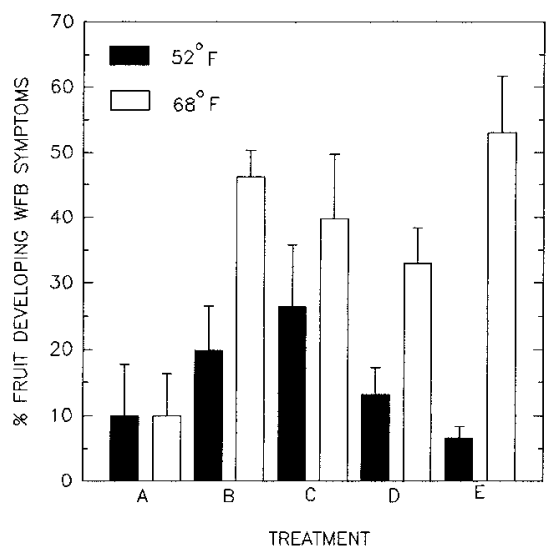

Fig. 1. Percent of watermelon fruit developing WF B symptoms in 1996 after 3 weeks storage at 52 or $68{ }^{\circ} \mathrm{F}$ $\left(11\right.$ or $20^{\circ} \mathrm{C}$ ). F ruit were treated as (A) control, healthy fruit with no contact with diseased fruit; (B) healthy and diseased fruit in contact with no abrasion treatment; (C) healthy unabraded fruit in contact with diseased abraded fruit; (D) healthy abraded fruit in contact with diseased unabraded fruit; and (E) healthy and diseased fruit, both abraded. B ars indicate SEM. after 1 week in storage. After 2 weeks in storage, deterioration of the diseased 'R oyal Sweet' fruit was so severe at both temperatures that it was impossible to move them and evaluate the 'Starbrite' without jeopardizing the experimental design. M any of the 'Royal Sweet' had literally liquefied and could not be handled. Evaluation of the 'Starbrite' fruit for transmission of WFB was postponed until week 3.

After 3 weeks, all of the diseased 'R oyal Sweet' fruit were removed from storage and the 'Starbrite' fruit were washed so that an evaluation for WFB transmission could be conducted. In the control groups (T reatment A), one 'Starbrite' fruit at each temperaturehad developed a small blotch. In both fruit the affected area was $<1.25$ inches ( 3 $\mathrm{cm}$ ) in diameter and the fruit were otherwise in good condition.

Transmission of WFB to healthy 'Starbrite' fruit that were paired in contact with diseased 'Royal Sweet' varied from $8 \%$ to $53 \%$ (Fig. 1). There was no significant effect of abrasion treatments on the transmission of WFB from 'R oyal Sweet' to 'Starbrite' compared with paired fruits that were not abraded. There was an increase in disease transmission in all four paired-fruit contact treatments compared with WFB symptom development in controls that were not in contact with a diseased fruit $(P<0.05)$. Storagetemperature significantly influenced the rate of WFB symptom development $(P=0.03)$, with greater frequency of development at $68^{\circ} \mathrm{F}$ than at $52^{\circ} \mathrm{F}$.

In 1997, 'Starbrite fruit examined after 1 or 2 weeks in contact with diseased 'Royal Charleston' did not exhibit any symptoms of WFB at either storage temperature. Atthe3-week examination, none of the 'Starbrite' fruit at 52 ' $\mathrm{F}$ exhibited WFB symptoms, but at $68^{\circ} \mathrm{F}, 3$ of the 22 'Starbrite' had very minor ( $<1$ inch $(2.5$ $\mathrm{cm}$ ) diameter) WFB symptoms. A cidovorax avenaesubsp. atrulli was isolated from two of thesethreefruit. T wo of the control fruit not in contact with other fruit also had developed very minor WFB symptoms at $68^{\circ} \mathrm{F}$.

\section{Discussion}

The severity of blotch symptoms did not increase dramatically postharvest on fruit that had $<4$ inches $(10 \mathrm{~cm})$ diameter symptomsat thetimeof harvest. Theslight increases of diseased fruit surface that were noted were more pronounced at $68{ }^{\circ} \mathrm{F}$ than at $52^{\circ} \mathrm{F}$. Symptomlessfruit harvested from an infested field had an extremely low incidence of development of WFB symptoms postharvest, and when symptoms did develop, they were minor and of no consequenceto themarketing of the fruit.

Watermelon fruit blotch was not transmitted from diseased to healthy fruit in the first week of storage at either temperature, but it wastransmitted from diseased to healthy fruit after 3 weeksin storage. The incidence of transmission was greater at $68{ }^{\circ} \mathrm{F}$ than at $52^{\circ} \mathrm{F}$ in the 1996 study. In 1997, this pattern was observed again, but the difference between temperatures was not statistically significant. Abrasion of thefruit surfaces does not appear to significantly influence disease transmission.

The fact that storage temperature influencesthefrequency of diseasetransmission, with more transmission at the higher temperature, suggests that appropriateprecooling of watermelonswill reduce postharvest incidence of fruit blotch. Watermelon fruit blotch likely can becontrolled in themarketing chain if all fruit with symptoms are excluded from harvest or are eliminated during packing, and if appropriatetemperature management is employed for storage and distribution.

\section{Literature cited}

Cook, W.P., A.P. Keinath, and R.P. Griffin. 1995. Growing watermelons in South Carolina. Clemson U niv. Coop. Ext. Serv. Bul. EB 121.

H opkins, D.L. 1989. Bacterial fruit blotch of watermelon: A new disease in the eastern U SA, p. 74-75. In: C. Thomas (ed.). Cucurbitaceae ‘89.

H opkins, D.L. 1997. Effect of seed contamination level on final incidence of bacterial fruit blotch of direct-seeded watermelon. Phytopathology 87:S44.

Hopkins, D.L., C.M. Thompson, and G.W Elmstrom. 1993. Resistance of watermelon seedlings and fruit to the fruit blotch bacterium. $\mathrm{H}$ ortScience 28:122-123.

H opkins, D.L. and G.W. Elmstrom. 1995. Comparison of diploid and triploid watermelon cultivars and breeding lines for susceptibility to bacterial fruit blotch, p. 152-154. In: G. Lester and J. Dunlap (eds.). Cucurbitaceae ' 94.

Latin, R.X. and D.L. H opkins. 1995. Bacterial fruit blotch of watermelon. The hypothetical exam question becomes reality. Plant D is. 79:761-765.

Webb, R.E. and R.W. Goth. 1965. A seedborne bacterium isolated from watermelon. Plant $D$ is. $R$ pt. 49:818-821.

Willems, A., M. Goar, S. Thielemans, M. Gills, K. Kersters, and J. DeL ey. 1992. Transfer of several phytopathogenic Pseudomonasspeciesto A cidovorax as A cidovorax avenae subsp. avenae subsp. nov. comb. nov., A cidovorax avenae subsp. citrulli, A cidovorax avenaesubsp. cattleyae, and A cidovorax konjaci. Intl. J. Syst. Bacteriol. 42:107-119. 